\title{
Microbial Fuels Cell-Based Biosensor for Toxicity Detection: A Review
}

\author{
Tuoyu Zhou ${ }^{1,+}$, Huawen Han ${ }^{1,+}$, Pu Liu $^{2}$, Jian Xiong ${ }^{3}$, Fake Tian ${ }^{3}$ and Xiangkai Li ${ }^{1, *}$ \\ 1 Ministry of Education, Key Laboratory of Cell Activities and Stress Adaptations, School of Life Science, \\ Lanzhou University, Tianshui South Road \#222, Lanzhou 730000, China; zhouty2016@lzu.edu.cn (T.Z.); \\ hanhw13@lzu.edu.cn (H.H.) \\ 2 Department of Development Biology Sciences, School of Life Science, Lanzhou University, \\ Tianshui South Road \#222, Lanzhou 730000, China; liupu@lzu.edu.cn \\ 3 Wuhan Optics Valley Bluefire New Energy Co., Ltd., Three Hubei Road, Wuhan East Lake Development \\ Zone \#29, Wuhan 430205, China; xiongjianly@163.com (J.X.); tianfakely@163.com (F.T.) \\ * Correspondence: xkli@lzu.edu.cn; Tel.: +86-931-891-2560; Fax: +86-931-891-2561 \\ + These authors contributed equally to this work.
}

Received: 29 July 2017; Accepted: 21 September 2017; Published: 28 September 2017

\begin{abstract}
With the unprecedented deterioration of environmental quality, rapid recognition of toxic compounds is paramount for performing in situ real-time monitoring. Although several analytical techniques based on electrochemistry or biosensors have been developed for the detection of toxic compounds, most of them are time-consuming, inaccurate, or cumbersome for practical applications. More recently, microbial fuel cell (MFC)-based biosensors have drawn increasing interest due to their sustainability and cost-effectiveness, with applications ranging from the monitoring of anaerobic digestion process parameters (VFA) to water quality detection (e.g., COD, BOD). When a MFC runs under correct conditions, the voltage generated is correlated with the amount of a given substrate. Based on this linear relationship, several studies have demonstrated that MFC-based biosensors could detect heavy metals such as copper, chromium, or zinc, as well as organic compounds, including $p$-nitrophenol (PNP), formaldehyde and levofloxacin. Both bacterial consortia and single strains can be used to develop MFC-based biosensors. Biosensors with single strains show several advantages over systems integrating bacterial consortia, such as selectivity and stability. One of the limitations of such sensors is that the detection range usually exceeds the actual pollution level. Therefore, improving their sensitivity is the most important for widespread application. Nonetheless, MFC-based biosensors represent a promising approach towards single pollutant detection.
\end{abstract}

Keywords: MFC; biosensors; toxicity detection; application; environmental monitoring

\section{Introduction}

Fast industrial growth has accelerated environmental pollution globally [1]. Moreover, environmental pollutants are widely distributed and diverse. Among environmental pollutants, heavy metals and organic compounds have attracted particular attention given their large presence in natural environments (soil, air, water, plants, etc.) [2,3]. More recently, according to the U.N. waste monitoring report, it is estimated that approximately 42 million tons of electronic waste is generated globally per annum, mainly composed of heavy metals and organic pollutants [4]. The Greenland MAP Core program has demonstrated organic pollutants in the Arctic show a decreasing trend, except for the polychlorinated biphenyl (PCB) compound group [5]. While the existence of pollutants represents an ecological risk, and also poses a threat to human health and the natural environment, bioremediation processes (e.g., microbial remediation) can remove or degrade heavy metals and organic pollutants. Pollution remediation is inevitably associated with the monitoring of toxic 
substances in environmental governance. Hence, real-time monitoring of toxicity components in natural environments is of paramount importance.

Fast sensing and analysis of toxic compounds is a great challenge due to their complexity. Traditional toxin detection methods focus on ultraviolet spectrometry and high performance liquid chromatography (HPLC) [6]; however, these analytical methods are usually time-consuming and unsuitable for in situ analysis. Biosensors have been developed as promising tools for fast and selective detection of various analytes [7]. The recognition elements integrated within traditional biosensors, which can be fluorescent molecules, enzymes, or immobilized microorganisms, are costly and require laborious implementation processes [8]. In addition, their low sensitivity and specificity further restricts the potential for large scale applications. Thus, developing a fast and cost-effective biosensor for toxicity detection is extremely urgent. Recently, microbial fuel cell (MFC)-based biosensors have shown great application prospects for environmental pollutant monitoring, since they offer an instant and convenient alternative, ensuring the potential for permanent and long-term monitoring $[9,10]$. They are usually composed of a cathode chamber and an anode chamber separated by a proton exchange membrane (PEM), allowing protons to migrate from the anode to the cathode and preventing oxygen diffusion into the anodic chamber (Figure 1). Anaerobic respiring bacteria are inoculated into the anodic compartment, where the microbes generate electrons and protons by consuming organic matter. Electrons are conveyed through the anode and pass through an external circuit to the cathode. Combined with the $\mathrm{O}_{2}$ from air, protons and electrons react in the cathodic chamber, and eventually form $\mathrm{H}_{2} \mathrm{O}$.

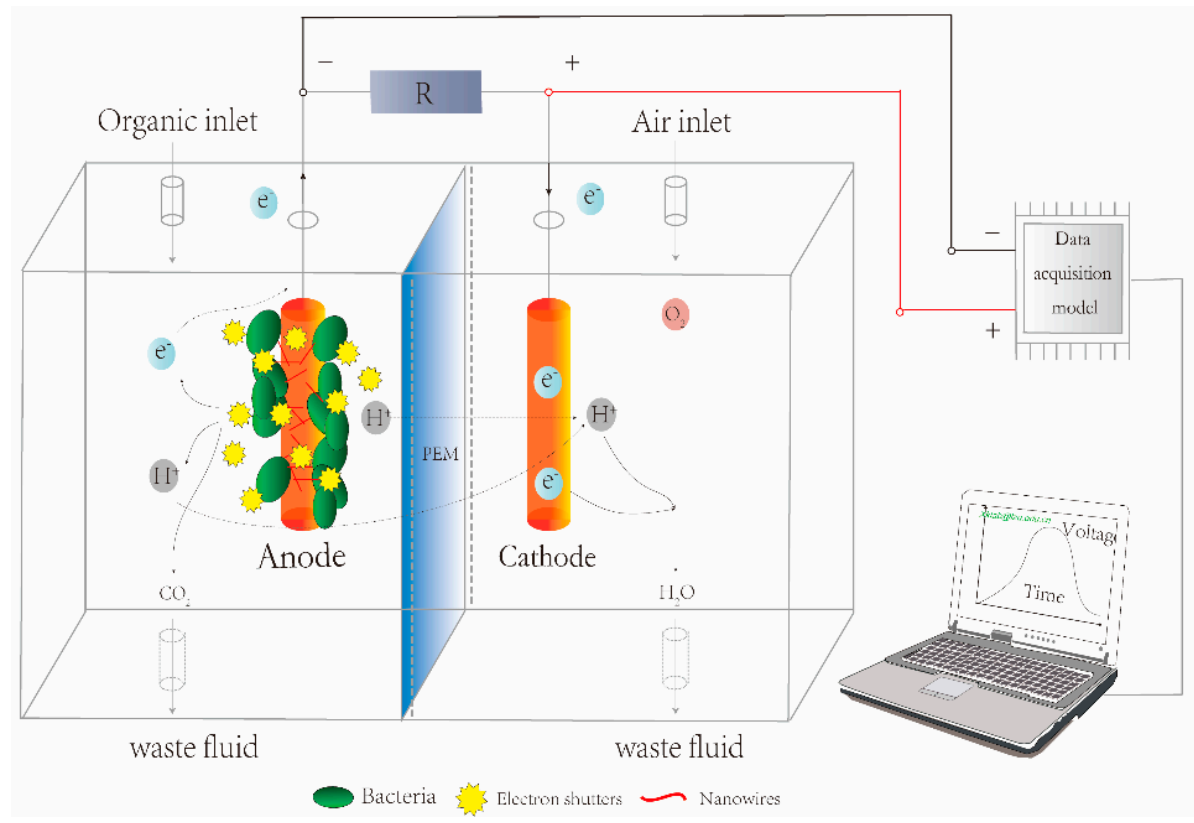

Figure 1. Diagram of a dual chamber microbial fuel cell (MFC).

Previously, MFC-based biosensors have been widely used for water quality testing through monitoring dissolved oxygen (DO), biological oxygen demand (BOD), and chemical oxygen demand (COD). However, these indicators cannot distinguish the dominant organic pollutants [10]. Using MFC-based biosensors for monitoring specific organic compounds may become a novel trend for their application. Although several reviews have focused on the topic of MFC-based biosensors, there is no report on MFC-based biosensors for specific substrates [7,11]. Here, we summarize the latest research outcomes and describes their sensing mechanism. We then further evaluate several factors influencing their behavior and discuss means by which their performances could by improved, more particularly regarding the choices of membrane types and anode materials. In addition, we investigate 
modified non-linear modelling techniques for MFC-based biosensors, and briefly present possible future research directions, particularly in terms of popularization and potential applications.

\section{The Mechanisms Governing MFCs Used as Biosensors}

The electrochemically active microorganisms (EAMs) in an MFC catalyze the degradation of an organic material (fuel), and the electrons subsequently released during this degradation process are transferred to the anode surface [12]. Therefore, the electricity generated by the MFC is the key parameter that directly reflects the metabolic activity of the specific microbes present at the anode. Thus, understanding of the electron generation mechanism of the MFC is important towards comprehending the analytical applications and operating procedures of MFC-based biosensors. Shewanella oneidensis MR-1 and Geobacter sulfurreducens have often been chosen as representative strains driving the mechanisms of extracellular electron transfer (EET). Based on the available studies, two mechanisms driving charge transfer from biofilms towards the anode surface have been proposed. One is the direct electron transfer (DET) and the other is mediated electron transfer (MET) (Figure 2).

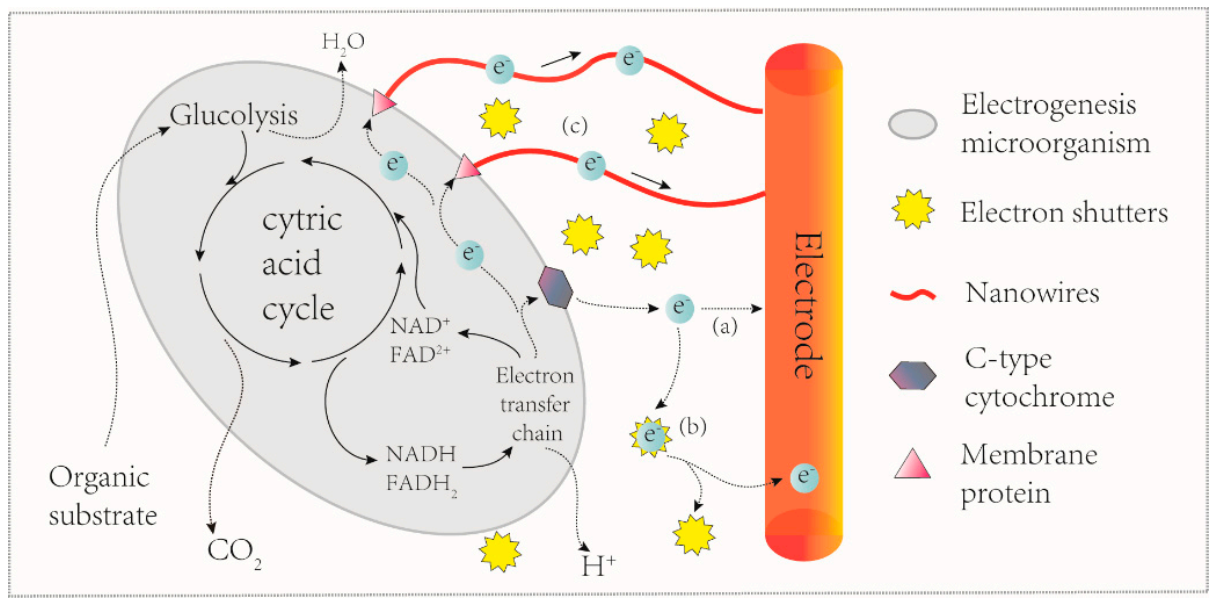

Figure 2. A schematic representation of three microbial extracellular electron transfer mechanisms at anode electrode of MFCs. (a) direct transfer via contact and c-type cytochromes; (b) indirect electron transfer by electron shuttles; (c) direct electron transfer by conductive nanowires.

Physical contact between bacterial cell membranes and the MFC anode is a prerequisite of DET. Moreover, the membrane-bound electron transport proteins of EAMs, including c-type cytochromes, multi-heme proteins and OmcZ, can transfer electrons from the inside of the bacterial cell to an outer-membrane $(\mathrm{OM})$ redox protein $[13,14]$. Some dissimilatory bacteria lack c-cytochromes and instead, use conductive filamentous extracellular appendages termed bacterial nanowires $[15,16]$. Regarding the MET pathway, flavins and riboflavins secreted by S. oneidensis MR-1 have been demonstrated as the electron shutters and dominate the extracellular electron transfer [17,18]. Furthermore, phenazines were also established as intrinsic electron shuttles in Pseudomonas species [19]. Although numerous compounds have been introduced into MFCs as exogenous redox mediators to facilitate the electron transfer to electrodes [20,21], these exogenous redox mediators achieved relatively low currents and required continuous addition of the exogenous compound.

As for a microbial biosensor, the current production performance of MFCs can be disturbed by various operational factors, including temperature, $\mathrm{pH}$, salinity, and anode potential [22]. If the MFC functions with non-saturated organic substrates condition, with the abovementioned parameters remaining constant, the biocatalytic activity of electricigens is directly associated with the variations in the concentration of the organic matter fed into the system. The number of electrons transferring to the anode keeps increasing until the concentration of the organic matter reaches a saturation point. This is the basic principle governing the use of MFCs as amperometric sensors for BOD detection in 
wastewater [23]. In contrast, when using saturated organic substrates, various concentrations of toxic compounds in the input stream can actually inhibit the microbial metabolism activity and substrates consumption, producing changes in the current generated [24].

An inhibition rate (I) has been presented to illustrate the effect of a toxic substance fed into the MFC-based biosensor, which can be calculated using the follow Michaelis-Menten Equation (1):

$$
\mathrm{I}(\%)=\frac{\mid \text { CYnor }- \text { CYtox } \mid}{\text { CY }} \times 100
$$

where $\mathrm{CY}$ is the Coulombic yield in each peak and it is calculated by integrating the electrical output over time; CYnor and CYtox represent the Coulombic yield in normal wastewater and toxic sample, respectively [25]. In this calculation method, a certain concentration of a toxic pollutant is injected into the anode chamber to observe the Coulombic output, in which three samples are typically utilized as the standard toxicity substrate, including chromium (acute toxin), iron (non-toxic metal) and acetate (organic substrate).

To be applied as a biosensor, the sensitivity of MFC is another significant parameter used to evaluate its functional characteristic. According to Equation (2):

$$
\text { sensitivity }=\frac{\Delta I}{\Delta c \cdot A}
$$

The sensitivity of a MFC-based biosensor is defined as the electrical signal change per unit change of analyte concentration. $\Delta I(\mu \mathrm{A})$ is the unit change in the current output; $\Delta c(\mathrm{mM})$ is the unit change in the analyte concentration; and $A$ is the electrode surface area $\left(\mathrm{cm}^{2}\right)$ [24].

While the bacterial consortium consumes the organic substrates and consequently releases the electron into anode, the potential difference will be generated between the anode potential and equilibrium redox potential of the substrate [26]. This potential difference is therefore known as the overpotential and its theoretical value can be calculated using the Nernst Equation (3):

$$
\eta=\mathrm{E}_{a n}-\mathrm{E}_{0}+\frac{\mathrm{RT}}{n F} \ln \frac{[\mathrm{ox}]}{[\text { red }]}
$$

where $\eta$ is the overpotential $(\mathrm{V}) ; \mathrm{E}_{a n}$ : the anode potential $(\mathrm{V}), \mathrm{E}_{0}$ : the standard potential of reaction $(\mathrm{V})$; $\mathrm{R}$ is gas constant $\left[\mathrm{J}(\mathrm{mol} \cdot \mathrm{K})^{-1}\right]$; $\mathrm{T}$, represents temperature $(\mathrm{K}), n$, the number of electrons released in the reaction; $F$ is Faraday's constant $\left(\mathrm{C} \mathrm{mol}^{-1}\right)$, and [ox] and [red] $\left(\mathrm{mol} \mathrm{L}^{-1}\right)$ are the concentrations of the oxidized and reduced species of the redox couple, respectively [27].

The overpotential disturbance generated by toxic compounds can be correlated to different energy losses at the anode. Under constant conditions, a polarization curve is useful towards evaluating the anode losses and showing the dependence of current on overpotential, combined with enzyme inhibition kinetics, which can be described by the Butler-Volmer-Monod (BVM) Equation (4):

$$
\mathrm{I}=\operatorname{Imax} \cdot \frac{1-e^{-n \cdot f}}{\beta_{1} \cdot K_{1} \cdot e^{-(1-\alpha) \cdot n \cdot f}+\beta_{2} \cdot K_{2} \cdot e^{-n \cdot f}+\beta_{3} \cdot(K m / S)+1} \cdot \beta_{4}
$$

In this model, the evaluation of the electric current under fixed overpotential could provide an enhanced sensitivity for a specific toxic compound. In principle, by observing the changes in parameters, the effect of four types of enzyme inhibition kinetics can be described, that can help distinguish between various types of toxicity [28]. Although this model cannot deliver a simultaneous estimation of substrate concentration and BVM parameters from current data, by using the weighted least-squares technique to reparametrize the polarization curve, the substrate concentration and consumption rate can be estimated, providing a protocol for on-line detection of toxicity [27].

The EAM enrichment in the anode compartment of a MFC-based biosensor plays an important role, not only as the biocatalyst for current generation from organic substrates, but also as the 
biological sensing element providing the response signal to various concentrations of toxic compounds. Two strategies have been adopted for the inoculation of EAMs for MFC-based biosensors. In one case, the inoculum source is a compound substance such as anaerobic sludge, soil, or domestic wastewater, which provides a bacterial consortium for the anode chamber [29-31]. Alternatively, pure cultures have been used as anode inoculum in recent studies [32-34].

Although the analytical performance parameters of MFC-based biosensors, such as detection time, saturation signal, and detection range, show no significant discrepancies when using either a bacterial consortium or specific bacteria as the source of inoculum, pure cultures could maintain high stability and uniformity [35]. Unlike when using a sole bacterial type in the anode chamber, the diversity of a bacterial consortium may vary with different substrates being fed into the system, which could consequently affect the performance of the MFC when used as a biosensor [36]. From another aspect, single bacteria is prone to be manipulated for constructing a more stable and viable toxicant detector. Therefore, employing the single strain as anode biological sensing elements should represent the future research direction towards developing of MFC-based biosensors.

\section{Analytical Applications of Microbial Fuel Cell-Based Biosensors}

A MFC-based biosensor can be defined as an analytical device, integrating bacteria as biological sensing elements to produce a signal proportional to the analyte concentration $[37,38]$. Compared with conventional biosensors, such as bluegill-, algal- or enzyme-based ones, MFC-based biosensors offer advantages in terms of stability and simplicity, and therefore, have been proposed as promising tools for analytical applications.

\subsection{MFC as VFA Biosensor}

Nowadays, biogas is regarded as a promising renewable alternative energy to replace fossil fuels. However, the unstable anaerobic digestion (AD) process is the main limitation regarding its technological application. To solve the problem, volatile fatty acids (VFAs) are regarded as crucial indicators for monitoring biogas generation [39]. Existing methods for VFA detection, such as high performance liquid chromatography (HPLC), gas chromatography (GC), colorimetric testing and titration, are complex and involve numerous steps [40,41]. Hence, developing a portable VFA determining device is essential for AD process monitoring. In recent years, MFC-based biosensors have been applied for VFA monitoring.

The primary study describing the quantification and analysis of dissolved VFAs was conducted in 2013. Acetate, butyrate and propionate were also discriminated by using Coulombic efficiency and a cyclic voltammetry method. Although the former would require excessive sampling times, a good linear relationship can be observed between the charge and individual VFA species concentration from 5 to $40 \mathrm{mg} \mathrm{L}^{-1}$ [42]. Compared to traditional AD, MFC could enhance the degradation rate of propionate and butyrate, indicating a more efficient method for VFA sensing and indeed organic matter removal.

Based on the principle of microbial desalination cells, Jin et al. [43] proposed a three-chamber VFA monitoring biosensor (Figure 3). In this device, the anaerobic digestion effluent was dosed into the middle chamber and then travelled toward the anode through the AEM, in which the ironized VFAs was utilized by exoelectrogenic microbes for producing electrons. The protons was separated by CEM and combined with the $\mathrm{O}_{2}$ to produce water in the cathode chamber. This kind of VFA biosensor showed a broad detection range from $170 \mathrm{mg} \mathrm{L}^{-1}$ to $3405 \mathrm{mg} \mathrm{L}^{-1}$ due to the separation of bulk solution and anodic microbial community. It also displayed a high selectivity since complex organic matter was retained by AEM which only allowed VFA transport through.

Later on, a microbial electrolysis cell (MEC) was used to facilitate the transportation of VFAs from the cathode compartment to the anode chamber supplemented with an external voltage, thereby shortening the response time. It should be noted this device only required $1 \mathrm{~h}$ with a high monitoring concentration of up to $1702 \mathrm{mg} \mathrm{L}^{-1}$. Furthermore, the actual performance of this biosensor was 
further investigated by using real AD effluents and the VFA measurements from the sensor showed no significance differences with those analyzed from GC [44]. The stability and reproducibility of device was achieved without membranes cleaning or replacement after 5 months of operation, demonstrating the robust of this kind of biosensor.

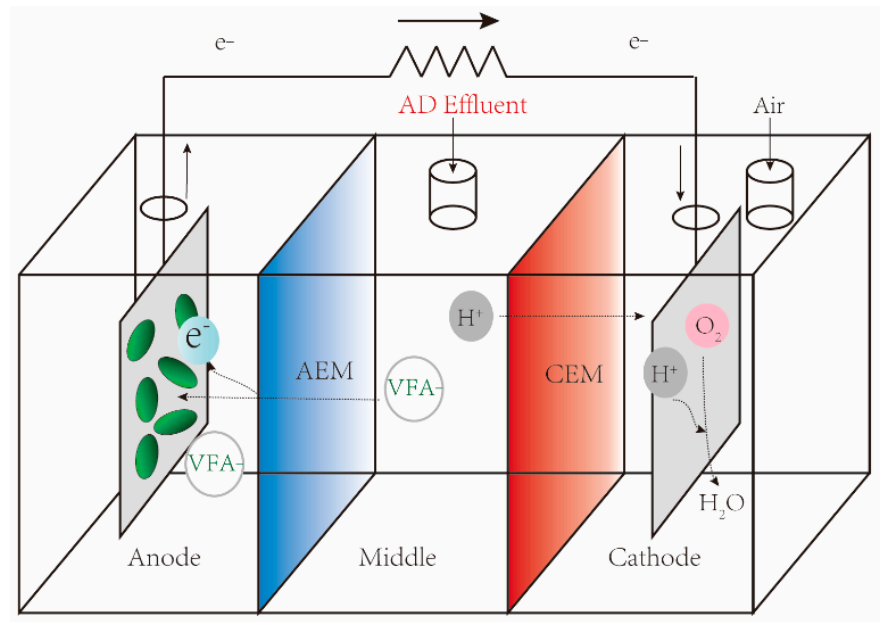

Figure 3. Schematic MFC-based VFA biosensor with three chambers. AEM: anion exchange membrane; CEM: cation exchange membrane.

As a matter of fact, a single-chamber MFC (SCMFC) is superior to a dual-chamber MFC by reason of its operability and compactness. Moreover, a study pointed out the SCMFC would be more sensitive [45]. Recently, an air-cathode MFC for online monitoring VFA in anaerobic digesters showed highly sensitive responses of electroactive biofilms with VFAs concentrations increase under four divergent organic wastes. The negative peak of current can be used as an early warning of microbial metabolic inhibition. However, when VFAs increased above $4000 \mathrm{mg} \mathrm{L}^{-1}$, electroactive bacteria were subjected to strong inhibition, thus affecting the response current output [46].

To date, MFC-based VFA biosensors show a broad application prospect for monitoring anaerobic digestion process with high sensitivity and comparatively wide response range; however, some issues should be solved in future works, including the effects of fermentation metabolites and other variation of divergent inhibitors. Besides, the behaviors of electroactive biofilms in anodic chamber under different conditions are worth of further investigated. As a result, the onsite operation of MFC-based VFA biosensors needs to be further exploration, especially regarding theirs durability over long term operation.

\subsection{MFC as BOD Biosensors}

Biochemical oxygen demand (BOD) is a crucial parameter used in water quality monitoring, which refers to the amount of dissolved oxygen that microorganisms consume during the oxidation of substances [47]. As a consequence of the significant population expansion and intensifying industrialization and civilization, large quantities of domestic or industrial wastewaters are discharged into rivers, ponds, reservoirs or other surface waters. In most cases, these effluent wastewaters contain very high BOD levels, which can cause severe water quality problems leading to eutrophication, dissolved oxygen depletion, or the death of aquatic organisms [48]. However, conventional methods are not suitable for real-time BOD monitoring, and even require external powered equipment. Thus, a lot of efforts have been directed toward developing MFC-based biosensors. In this section, a brief summary on MFC-based BOD biosensors is provided in Table 1. 
Table 1. MFCs as BOD biosensors.

\begin{tabular}{|c|c|c|c|c|c|c|}
\hline $\begin{array}{c}\text { Source } \\
\text { Inoculum }\end{array}$ & $\begin{array}{c}\text { MFC } \\
\text { Configuration }\end{array}$ & $\begin{array}{l}\text { Electrode } \\
\text { Material }\end{array}$ & $\begin{array}{l}\text { Detection Range } \\
\left(\text { BOD, } \mathrm{mg} \mathrm{L}^{-1} \text { ) }\right.\end{array}$ & $\begin{array}{c}\text { Saturation } \\
\text { Signal }\end{array}$ & $\begin{array}{l}\text { Response } \\
\text { Time (min) }\end{array}$ & Reference \\
\hline $\begin{array}{l}\text { Clostridium } \\
\text { butyricum }\end{array}$ & Double chamber & $\begin{array}{c}\text { Anode: Pt; } \\
\text { cathode: Carbon }\end{array}$ & $10-300$ & $0.120 \mathrm{~mA}$ & 70 & [49] \\
\hline MFC effluent & Double chamber & Graphite felt & $2.58-206.4$ & $1.1 \mathrm{~mA}^{\mathrm{a}}$ & $30-600$ & [50] \\
\hline River sediment & Double chamber & Graphite felt & 5 & ND & 180 & [51] \\
\hline MFC effluent & Double-chamber & ND & $50-100$ & $1.85 \mathrm{~mA}^{\mathrm{a}}$ & 36 & [52] \\
\hline $\begin{array}{l}\text { Activated } \\
\text { sludge }\end{array}$ & Double chamber & Graphite felt & 23-200 & $6 \mathrm{~mA}^{\mathrm{a}}$ & 60 & [53] \\
\hline River sediments & Double chamber & Graphite felt & $2-10$ & $6 \mathrm{~mA}$ & 60 & [54] \\
\hline $\begin{array}{l}\text { Activated } \\
\text { sludge }\end{array}$ & Single chamber & Graphite roll & $\begin{array}{c}\text { Glucose: } \\
1000-25,000^{\mathrm{b}}\end{array}$ & $1.6 \mathrm{mv}^{\mathrm{a}}$ & 60 & [55] \\
\hline $\begin{array}{c}\text { Primary } \\
\text { wastewater }\end{array}$ & Single chamber & Carbon cloth & COD: $50-1000^{\mathrm{b}}$ & $0.4 \mathrm{~mA}$ & 40 & [56] \\
\hline $\begin{array}{c}\text { Domestic } \\
\text { wastewater }\end{array}$ & Double chamber & Carbon paper & $17-183$ & $222 \mathrm{~mA}$ & 30 & [57] \\
\hline $\begin{array}{l}\text { Underground } \\
\text { water }\end{array}$ & Single chamber & Carbon paper & $10-250$ & $233 \mathrm{~mA}$ & $<40.2$ & [58] \\
\hline $\begin{array}{l}\text { Activated } \\
\text { sludge }\end{array}$ & Double chamber & Carbon cloth & $50-650$ & $0.6 \mathrm{~mA}^{\mathrm{a}}$ & 80 & [59] \\
\hline $\begin{array}{l}\text { Neat human } \\
\text { urine }\end{array}$ & Single chamber & Carbon fibre & Urine: $67-813^{b}$ & $297 \mathrm{mV}$ & $69-960$ & [9] \\
\hline
\end{tabular}

ND: No data available in original work. ${ }^{\text {a }}$ : Estimated using data presented by the authors. ${ }^{b}$ : BOD monitoring capability was demonstrated by using artificial wastewater as the exemplar substrate.

The first MFC-based BOD biosensor could only provide an estimated BOD value for industrial wastewater [49]. However, a subsequent study carried out over 5 years confirmed that the MFC has stable performance for BOD monitoring with the limit of detection (LOD) at $2.58 \mathrm{mg} \mathrm{L}^{-1}$ [50]. In 2007, Kumlanghan et al. [55] developed a SCMFC for rapid estimating the content of labile organic carbon. In this work, glucose solution was used to simulate the organic matter and the response time was estimated at around 3 to $5 \mathrm{~min}$. The capacity of SCMFC BOD biosensor was also tested by using actual effluent with a very high reproducibility during 7 months of operation [56]. In this study, a smaller reactor (i.e., $12.5 \mathrm{~mL}$ ) could provide a higher Coulombic efficiency than a larger one (i.e., $25 \mathrm{~mL}$ ). A simplified diagram of SCMFC based BOD biosensor is shown in Figure 4, in which the anode and cathode were placed in both sides of a cell. The sample was injected from the sampling port and BOD concentration was therefore determined by monitoring the variation of voltage in the MFC.

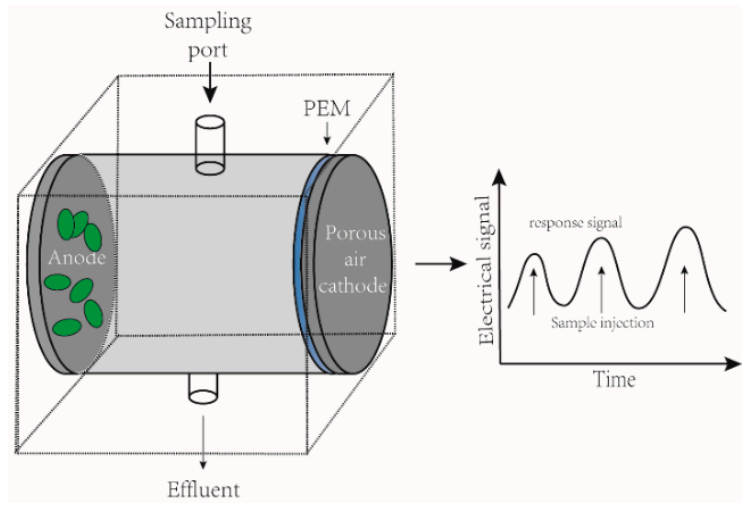

Figure 4. Simplified view of a single-chamber MFC-based BOD biosensor.

High redox potential electron acceptors in the anode chamber decrease the signal output obtained from MFCs. Chang et al. [60] demonstrated that respiratory inhibitors (e.g., azide and cyanide) can eliminate the inhibitory effect and significantly improve the MFC performance as a BOD biosensor. 
In the absence of the electron acceptors, the addition of azide and cyanide did not influence the signal. Besides, the oxygen diffusion into the anode chamber is a serious problem for Coulombic yield, thus affecting the metabolic activity of anaerobic microbes and the sensitivity of BOD biosensors. To correct the defect of this kind of biosensors, a SCMFC, assembled using sulfonated polyether ether ketone (SPEEK), remarkably enhanced the response of this MFC due to its low oxygen permeability. Its sensing range was $62.5 \%$ higher than that of Nafion, reaching $650 \mathrm{mg} \mathrm{L}^{-1}$ [59].

In situ real-time monitoring of wastewater is meaningful in practical applications, as primary effluents usually contain complicated biodegradable organics and toxic pollutants. An autonomous MFC can be operated for a long time with good characteristics, which indicated the potential for online BOD monitoring [9]. This biosensor is constructed with four MFCs and an energy management system. When the concentration of urine was over an appropriate limit, the sensor could produce a sound and light alarm, lasting for at least 2 days. Similarly, other studies have investigated the possibility of continuously monitoring BOD [53,54]. These results revealed the response current can be proportional to artificial wastewater concentration after a long term hydraulic retention. Peixoto et al. [58] also proposed a submersible MFC (SMFC) for onsite continuous determination of the BOD level of groundwater. This device demonstrated a good stability and its measurable concentration could reach as high as $250 \mathrm{mg} \mathrm{L}^{-1}$.

Although almost all BOD biosensors were applied to monitor high BOD values in industrial wastewaters, several studies focused on the determination of low BOD values since the secondary effluents and surface water usually contain low concentrations of organic compounds [54]. In these low BOD biosensors, $\mathrm{O}_{2}$-reducing activity at the cathode is considered as a key factor. Kang et al. [51] therefore reported a MFC acting as a low BOD biosensor with a LOD at $5 \mathrm{mg} \mathrm{L}^{-1}$ when using a cathode with better affinity for $\mathrm{O}_{2}$.

To shorten the response time of the BOD biosensor, the dynamic behavior of MFC was analyzed and optimized. Moon et al. [52] suggested the fuel-feeding rate of MFC should be maintained at $0.53 \mathrm{~mL} \mathrm{~min}^{-1}$, leading to the shortest response time. The experiment results also showed the response time could dramatically reduce from $36 \mathrm{~min}$ to $5 \mathrm{~min}$ while the anode volume of MFC decreased from $25 \mathrm{~mL}$ to $5 \mathrm{~mL}$.

\subsection{MFC as Toxicants Biosensors}

Online monitoring of various toxicants from industrial or domestic wastewaters is a requisite for water resource cyclic utilization and public health safety. Present chemical detection sensors are complicated and involve high operational costs. MFCs can provide a low maintenance and long-term stable solution to this problem. Toxic components can affect the activity of electrogenic microorganisms in biofilms, which contributes to a sudden change (either fall or rise) in the voltage (Figure 5). Depending on the type of substrates being monitored, MFC-based toxicity biosensors could be divided into two main categories i.e., heavy metals biosensors and organic matter biosensors. However, in most cases, the parameters used to establish this classification are ambiguous, since toxin biosensors often display overlapping functions and characteristics.

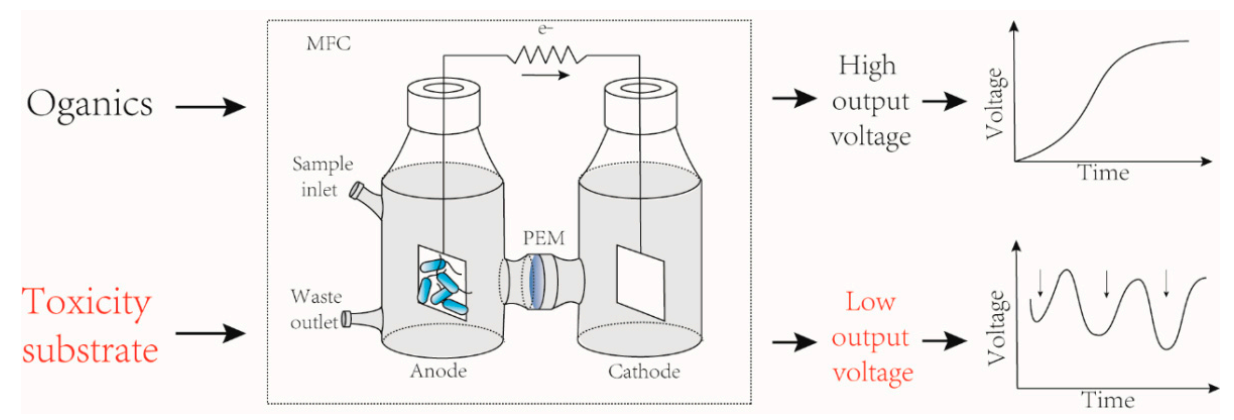

Figure 5. A typical dual-chamber microbial fuel cell used as a toxicity biosensor. 


\subsubsection{MFCs as Heavy Metal Biosensors}

Heavy metals represent a widely distributed source of pollution, resulting in a series of organs and tissues damage. For example, Hexavalent chromium $\left(\mathrm{Cr}^{6+}\right)$ is a strong carcinogenic substrate. The monitoring of heavy metals through MFCs has grown in recent years. Table 2 provides a review of functional characteristics and analytical performances of MFC-based heavy metal biosensors.

Kim et al. [25] reported that $\mathrm{Hg}^{2+}$ or $\mathrm{Pb}^{2+}\left(1-10 \mathrm{mg} \mathrm{L}^{-1}\right)$ could be detected by using a dual-chamber MFC. However, this work only considered limited concentrations of heavy metals. Lately, a MFC was utilized towards monitoring the effects of $\mathrm{Cu}^{2+}$ stress on soil microorganisms. The electric signals obtained with glucose-amended soil can be used to evaluate the eco-toxicity of $\mathrm{Cu}^{2+}$ with the LOD ranging from 50 to $400 \mathrm{mg} \mathrm{L}^{-1}$ [30].

Iron-oxidizing bacterial consortia can be enriched with $\mathrm{Fe}^{2+}$ as the sole electron donor [61]. According to this phenomena, Tran et al. [62] therefore constructed a MFC-based $\mathrm{Fe}^{2+} / \mathrm{Mn}^{2+}$ biosensor by inoculating this specific bacterial consortia as anodic electricigens. A linear correlation could be achieved between the current and the $\mathrm{Fe}^{2+}$ concentration in the range of $168-1120 \mathrm{mg} \mathrm{L}^{-1}$ while the response concentration of $\mathrm{Mn}^{2+}$ was less than $165 \mathrm{mg} \mathrm{L}^{-1}$. An early $\mathrm{Cr}^{6+}$ warning device was also presented, in which Ochrobactrum anthropi YC152 was incubated as the anodic microorganism catalyst. The results indicated a stable performance between the concentration of $\mathrm{Cr}^{6+}$ ranging from 0.0125 to 0.3 or 0.3 to $5 \mathrm{mg} \mathrm{L}^{-1}$ [32].

By using a batch-mode cube MFC, a sensitive shock (sudden change in toxin concentration) biosensor with a reasonable selectivity has been systematically explored. Three heavy metals, including $\mathrm{Cr}^{6+}, \mathrm{Fe}^{3+}$ and NaOAc can be effectively differentiated. The authors also investigated the effect of mixture shock and the results showed the mixed solution with the $8 \mathrm{mg} \mathrm{L}^{-1} \mathrm{Cr}^{6+}$ and $200 \mathrm{mg} \mathrm{L}^{-1}$ $\mathrm{NaAc}$ caused a sharp voltage drop within $30 \mathrm{~min}$ [63]. In addition, a study has been performed to assess the solitary and joint biotoxicities of heavy metals by employing a single-chamber MFC [64]. The results of binary mixtures of pollutants showed the effect of $\mathrm{Cu}^{2+}$ and acephate was antagonistic at $2 \mathrm{mg} \mathrm{L}^{-1}$ while was synergistic at 6 and $10 \mathrm{mg} \mathrm{L}^{-1}$, and $\mathrm{Cd}^{2+}$ and $\mathrm{Ni}^{2+}$ were synergistic between $0.2-1.0 \mathrm{mg} \mathrm{L}^{-1}$.

The ability to monitor the toxicity of multiple heavy metals could be more practical in application. In 2005, Lee et al. [65] developed a dual MFC system for the monitoring of twelve types of metal. The minimum response concentration of each metal was less than $1.0 \mathrm{mg} \mathrm{L}^{-1}$. Later on, using six selected heavy metals, with the LOD at $2 \mathrm{mg} \mathrm{L}^{-1}$, to simulate the high or low toxicity, a dual-chamber MFC showed an excellent ability for real-time monitoring toxicity substance [29].

In water clarification, flocculants are widely applied around the world. However, several reports demonstrated that alum can inhibit microorganism activity and event causes nerve poisoning after entering the human body $[66,67]$. Due to the influence of complex flocs, the in situ evaluation of alum toxicity is quite difficult by using electrochemical methods. A MFC type alum biosensor was therefore designed since the biofilm can be enmeshed inside the flocs [64]. Based on the change of biofilm activity on the electrode, this device could monitor alum concentration range from $0 \mathrm{mg} \mathrm{L}^{-1}$ to $500 \mathrm{mg} \mathrm{L}^{-1}$.

In general, exoelectrogenic microorganisms in MFCs are heterotrophic, utilizing chemical substrates as their energy resources. Photosynthetic microbial fuel cells (PMFC) represent another strategy by employing the autotrophic microbes as electron donors [68]. They have been applied toward renewable and sustainable electricity production [69]. Recently, Labro et al. [70] proposed a PMFC-based biosensor for monitoring copper, thallium and zinc, in which the electrode surface dwelled in algae and cyanobacteria. This indicates the utility of PMFCs as potential environmental biosensors. 
Table 2. MFCs as heavy metal biosensors.

\begin{tabular}{|c|c|c|c|c|c|c|c|}
\hline Heavy Metals & Source Inoculum & $\begin{array}{c}\text { MFC } \\
\text { Configuration }\end{array}$ & $\begin{array}{l}\text { Electrode } \\
\text { Material }\end{array}$ & Voltage or Current & Inhibition Ratio & Detection Range ( $\mathrm{mg} \mathrm{L}^{-1}$ ) & Reference \\
\hline $\mathrm{Hg}, \mathrm{Pb}$ & Activated sludge & Double chamber & Carbon felt & $0.026-0.040 \mathrm{~mA}$ & - & $1-10$ & [25] \\
\hline $\mathrm{Fe}, \mathrm{Mn}$ & $\begin{array}{l}\text { Iron-oxidizing bacterial } \\
\text { consortia }\end{array}$ & Double chamber & Graphite rod & $0.4-0.6 \mathrm{~mA} 0.1-0.3 \mathrm{~mA}$ & - & Fe: $168-1120$ Mn: 5.5-165 & [62] \\
\hline $\mathrm{KAl}\left(\mathrm{SO}_{4}\right)_{2} \cdot 12 \mathrm{H}_{2} \mathrm{O}$ & MFC effluent & Double chamber & Glassy carbon & $6-6.75 \mathrm{~A} \mathrm{~m}_{2}^{-1 \mathrm{a}}$ & - & $50-500$ & [66] \\
\hline $\mathrm{Cu}$ & Soil & Double chamber & Carbon felt & $52-354 \mathrm{mV}$ & - & $50-400$ & [30] \\
\hline $\mathrm{Cr}, \mathrm{Fe}$ & Fresh wastewater & Single chamber & Carbon felt & $\begin{array}{l}53-125 \mathrm{mV} \\
118-121 \mathrm{mV}\end{array}$ & - & $\begin{array}{l}\text { Cr: } 1-8 \\
\text { Fe: } 1-48\end{array}$ & [63] \\
\hline $\mathrm{Cr}$ & $\begin{array}{l}\text { Ochrobactrum anthropi } \\
\text { YC152 }\end{array}$ & Double chamber & $\begin{array}{l}\text { Plain porous } \\
\text { carbon paper }\end{array}$ & $81-258 \mathrm{mV}$ a & - & $0.0125-5$ & [32] \\
\hline $\mathrm{Cu}$ & Domestic wastewater & Single chamber & Carbon felt & - & $30-85 \%$ & $5-7$ & [71] \\
\hline $\mathrm{Cu}, \mathrm{Ni}, \mathrm{Cd}$ & Activated sludge & Single chamber & Carbon cloth & - & $\begin{array}{l}\text { Cu: } 7.5-22.5 \% \\
\text { Cd: } 10-60 \% \\
\text { Ni: } 3-10 \% \text { a } \\
\end{array}$ & $\begin{array}{l}\text { Cu: } 1-10 \\
\text { Cd: } 0.1-1.0 \\
\text { Ni: } 0.1-1.0\end{array}$ & [64] \\
\hline $\mathrm{Cu}, \mathrm{Zn}$ & $\begin{array}{l}\text { Paulschulzia pseudovolvox; } \\
\text { Cyanobactera CAWBG64 }\end{array}$ & Double chamber & Carbon cloth & - & $\begin{array}{l}\text { Cu: } 0-115 \% \\
\text { Zn: } 0-100 \%{ }^{\text {b }}\end{array}$ & $\begin{array}{l}\text { Cu: } 0.063-0.189 \\
\text { Zn: } 0.065-0.195\end{array}$ & [70] \\
\hline $\mathrm{Cu}, \mathrm{Hg} \mathrm{Zn}, \mathrm{Cd} \mathrm{Pb}, \mathrm{Cr}$ & Anaerobic sludge & Double chamber & Graphite felts & - & $\begin{array}{c}\text { Cu: } 7.9-18.48 \% \\
\text { Hg: } 13.99 \% \\
\text { Zn: } 8,81 \% \\
\text { Cd: } 9.29 \% \\
\text { Pb: } 5.59 \% \\
\text { Cr: } 1.95 \%\end{array}$ & Other metals: 0-2 & [29] \\
\hline $\mathrm{Cu}, \mathrm{Zn} \mathrm{Cr}, \mathrm{Cd}$ & Anaerobic sludge & Double chamber & Carbon felt & - & $\begin{array}{c}\text { Cu: } 1.02-9.31 \% \\
\text { Zn: } 0.70-4.16 \% \\
\text { No data for } \mathrm{Cr} \text { and Cd }\end{array}$ & $\begin{array}{c}\text { Cu: } 1-25 \\
\text { Zn: } 15-80 \\
\text { Cr: } 0.3-1 C d: 0.4-10\end{array}$ & [72] \\
\hline
\end{tabular}

${ }^{a}$ : Estimated using data presented by the authors. ${ }^{b}$ : Electrogenesis effect. 


\subsubsection{MFCs as Organic Toxin Biosensors}

Organic toxins are other common pollution substances found in wastewater, which generally contribute to eutrophication and represent threats to public safety [6]. Table 3 lists the characteristics and performances of organic toxin biosensors employing MFCs.

The toxicity of pesticides such as diazinon and polychlorinated biphenyls (PCBs), has been investigated in an early work by using a dual-chamber MFC [25]. In this study, the detection range of diazinon and PCBs was 1 to $10 \mathrm{mg} \mathrm{L}^{-1}$ and 1 to $5 \mathrm{mg} \mathrm{L}^{-1}$, respectively. Silicon wafers can be embedded as micro-size electrode elements combined with deep reactive ion etching and standard photolithography. Davila et al. [33] invented a miniaturized MFC as formaldehyde biosensor. This simple and compact apparatus is composed of a proton exchange membrane placed between two silicon plates, further developed into toxicity monitoring equipment. The maximum power density of the micro-fabricated MFC can reach $6.5 \mu \mathrm{W} \mathrm{cm}{ }^{-2}$, which is significantly higher than the maximum power density of $4.4 \mu \mathrm{W} \mathrm{cm} \mathrm{cm}^{-2}$ in a macro-size fuel cell.

Currently, Shewanella have been shown as a promising electrogenic bacterium and is extensively used for current generation in MFCs [73,74]. According to the Coulombic response of S. oneidensis MR-1 under various toxic substance concentrations, Wang et al. proposed a single-chamber bio-electrochemical systems (BES), and formaldehyde was selected as the typical toxic compound to assess its performance [34]. When $0 \mathrm{mV}$ overpotential was supplied on the anode, the electric response obtained over the concentration range from $100 \mathrm{mg} \mathrm{L}^{-1}$ to $1000 \mathrm{mg} \mathrm{L}^{-1}$ only requires $2.8 \mathrm{~h}$.

In chemical industry wastewaters, $p$-nitrophenol (PNP) is one of the most commonly found contaminants [75]. The use of physicochemical methods, such as ultraviolet spectrometry, gas chromatography, is unsuitable for in situ real-time monitoring of PNP. Aiming to solve this issue, a specific MFC biosensor for PNP, using Pseudomonas monteilii LZU-3, was presented. Moreover, this biosensor showed excellent stability and specificity in regard to the detection of PNP in wastewater containing various additional aromatic compounds (e.g., 2-nitrophenol, 3-nitrophenol, and nitrobenzene) and metal ions (e.g., $\mathrm{Fe}^{2+}, \mathrm{Zn}^{2+}, \mathrm{Na}^{+}$). The authors of this study also developed a portable device for in situ real-time monitoring and the maximum PNP response concentration could be up to $50 \mathrm{mg} \mathrm{L}^{-1}$ [35].

With levofloxacin (LEV) as drug resistance is increasingly occurring, ascribed to the extensive use in the treatment of bacterial infections, a SCMFC was presented for detecting trace LEV concentration [31]. The SCMFC exhibited lasting stability for online monitoring of LEV and its response time only required $5 \mathrm{~min}$. 
Table 3. MFCs as organic toxin biosensors

\begin{tabular}{|c|c|c|c|c|c|c|c|}
\hline Organic Substrate & Source Inoculum & MFC Configuration & Electrode Material & $\begin{array}{c}\text { Voltage or } \\
\text { Current }\end{array}$ & $\begin{array}{c}\text { Inhibition } \\
\text { Ratio }\end{array}$ & $\begin{array}{l}\text { Detection Range } \\
\left(\mathrm{mg} \mathrm{L} \mathrm{L}^{-1}\right)\end{array}$ & Reference \\
\hline Diazinon & Activated sludge & Double chamber & Carbon felt & - & $55-61 \%$ & $1-10$ & [25] \\
\hline Polychlorinated biphenyls & Activated sludge & Double chamber & Carbon felt & - & $29-38 \%$ & $1-5$ & [25] \\
\hline Acephate & Activated sludge & Single chamber & Carbon cloth & - & $8.54-13.34 \%$ & $1-7$ & [64] \\
\hline Glyphosate & Cyanobacteria CAWBG64 Paulschulzia pseudovolvox & Double chamber & Carbon cloth & $0-125 \%$ & - & $0.169-0.507$ & [70] \\
\hline Formaldehyde & Geobacter sulfurreducens & Double chamber & $\mathrm{Ti} / \mathrm{Ni} / \mathrm{Au}$ layer & $0-200 \mathrm{mV}$ & - & 100 & [33] \\
\hline Formaldehyde & Shewanella oneidensis MR-1 & Single chamber & Graphite rod & $0-200 \mathrm{mV}$ & - & 100-1000 & [34] \\
\hline$p$-Nitrophenol & Pseudomonas monteilii LZU-3 & Double chamber & Carbon felt & $115-150 \mathrm{mV}$ & - & $50-200$ & [35] \\
\hline Formaldehyde & Wild-type Shewanella oneidensis & Single chamber & Carbon cloth & $0.014-0.023 \mathrm{~mA}$ & - & $10-100$ & [76] \\
\hline Levofloxacin & No Data & Single chamber & Carbon felt & $0.41-0.2 \mathrm{~mA}$ & - & $0.0001-1$ & [31] \\
\hline Formaldehyde & MFC effluent & Double chamber & Graphite felt & $0.22-0.5 \mathrm{~mA}$ & - & 5-100 & [77] \\
\hline
\end{tabular}




\subsection{Comparison of Different Biosensors}

MFC-based biosensors have been developed as stable sensing devices to monitor toxins. However, the characteristics of MFC-based biosensors vary with the construction of the MFC, substrates, solution and microbes. For example, the detection limits this kind of biosensors are restricted to toxins (BOD, heavy metal and organic toxins) at the concentrations below $2 \mathrm{mg} \mathrm{L}^{-1}, 0.063 \mathrm{mg} \mathrm{L}^{-1}$ and $0.169 \mathrm{mg} \mathrm{L}^{-1}$, respectively, which could differ from the actual concentration in the environment [54,70]. In contrast, enzyme-based biosensors can provide a very high specificity for their substrates or inhibitors with detection limits reach $0.003 \mathrm{mg} \mathrm{L}^{-1}$ [78], but their application in biosensor construction is restricted by the required tedious and time-consuming enzyme purification. On the other hand, in addition to acting as prosthetic groups of an enzyme, it was well-known that the majority of toxins can distort the protein backbone, leading to enzyme denaturation. Meanwhile, the slow heterogeneous electron transfer from the enzyme to the electrode interface also impedes the wide application of efficient enzymatic biosensors. Microbial biosensors could circumvent the deficiency of enzyme biosensors since the microorganisms encode multiple enzymes in suitable condition and provide a robust reactor. In fact, the LOD of optical microbial biosensors (i.e., bioluminescence and fluorescence biosensors) could reach 0.03 and $0.02 \mathrm{mg} \mathrm{L}^{-1}$, respectively, which offer advantages of compactness, flexibility, and a small probe size $[79,80]$.

MFC-based biosensors are considered as a portable and cost-effective detection device for bioactive toxicants comparing with other biosensors. For enzyme-based biosensors, it is essential to maintain a specific environment to avoid enzymatic inactivation. Moreover, the immobilization and purification of enzyme increases the cost of enzyme biosensors and the detection process must rely on specific equipment (e.g., an ultraviolet spectrophotometer), thus is difficult to achieve online monitoring. Likewise, the other types of microbial biosensors need to immobilize the bacteria to the support matrices, and it also complex transducers to achieve the conversion between signal and substrates. On the contrary, the electronic signal output of MFC-based biosensors can directly reflect the toxin concentration.

\section{The Performance of MFC-Based Biosensors}

MFC-based biosensors offer new opportunities for fast monitoring of water quality and food analysis [81,82]. However, the application and performance of MFC-based biosensors is restricted to the detection of analytes at the concentrations below $0.063 \mathrm{mg} \mathrm{L}^{-1}$ [54]. Furthermore, the complex substrates present in wastewaters inordinately affect the sensitivity and stability of MFC-based biosensors. Thus, there is an urgent need to address these two limitations of MFC-based biosensors.

\subsection{Factors That Influence MFC-Based Biosensors}

The rate of extracellular electron transfer (EET) is used to characterize MFC-based biosensors' operation. The anodic biofilm formation efficiency was found to enhance the EET in the absence of mediators. Electrolyte $\mathrm{pH}$ affects dramatically the synthesis of riboflavin from Shewanella, resulting in the variation of the electrical output for MFCs [18]. Intriguingly, supplementation with riboflavin will decrease the internal resistance and thus reduces the energy loss of the system [83]. However, the use of exogenous mediators might not be applicable to the actual application of MFC, because this external operation may lead to the toxicological problems.

Pretreatment of the carbon mesh has an impact on suitable MFC performance. For example, a carbon mesh treated through the ammonia gas process increased the power to $51 \mathrm{~W} \mathrm{~m}^{-3}$ [84]. Besides, the surface modifications of anode materials represent the most important factors. Ideal anodic materials should have the following features: biocompatibility, conductivity, and chemical stability. The modification of the anode provides a high surface area for the formation of biofilms and increases the power output. Furthermore, the anode type can directly influence the MFC-based biosensor performance; Kong et al. [85] used niobium-doped lanthanum calcium ferrite perovskite as a novel 
electrode material in MFCs, showing promising results. Some studies of electrode modification also claimed that it can reduce the internal resistance of the system and the start-up time of the reactor $[86,87]$.

In a study focusing on the effects of operating parameters, where a MFC-based biosensor was inoculated with known mixed cultures to determine the BOD concentration, the results showed that methionine, phenylalanine, and ethanol were poor fuels for electricity generation, whereas monosaccharides gave good results [88]. Ji et al. [89] found that electrical signal feedback was more sensitive than $\mathrm{pH}$ in the integrated MFC-UASB system, and that limits of sensitivity ranged from $3 \times 10^{-5} \mathrm{~V}\left(\mathrm{mg} \mathrm{L}^{-1}\right)^{-1}$ to $8 \times 10^{-5} \mathrm{~V}\left(\mathrm{mg} \mathrm{L}^{-1}\right)^{-1}$ for different concentration ranges. Another study revealed that the type of ion exchange membrane, including cation exchange, anion exchange, monovalent cation exchange, and bipolar membranes, had no significant impact on the sensitivity of MFC-based biosensors [90]. However, the sensitivity is higher at higher overpotential and therefore, at higher current density. Meanwhile, Chen et al. reported that PNP concentration, $\mathrm{pH}$, and temperature influence the performance of PNP biosensors [35]. Hence, in order to achieve a stable baseline current under non-toxic conditions, it is imperative that a MFC-based biosensor should be operated at controlled anode potential, $\mathrm{pH}$ and saturated substrate concentrations [91].

\subsection{Performance Improvement of MFC-Based Biosensors}

Although MFC-based biosensors hold great potential as being self-sustainable, without the need for additional signal transducers or external power sources, a change in the concentration of the targeted substrates in the exposed aquatic environmental affects electrogenic microorganisms' metabolic activities, restricted to the output electrical signal. Thereby, extensive efforts are necessary to improve the capacities of MFC-based biosensors for widespread use.

Improvements in biosensor performance have been achieved with micro-sized MFCs. The miniaturization of biosensor accelerates the cell attachment to the electrodes in anode and then reduces the response time. However, micro-sized MFCs are generally limited as biosensor because of microbubbles interferences in the narrow chamber and its high sensitivity to flow rate variations [92]. When a bubble trap and three electrodes were introduced into the sensing surface, undesirable bubbles can be captured by this trap and thereby provided a stable anodic potential, which enhanced the sensitivity and reliability of this miniature MFC as toxin biosensor [81]. Besides reducing the cost, the miniaturization of MFC can also improve the mass transfer inside the reactor, reducing the difference in concentration of analyte between the input and biofilm, thus leading to a more reliable sensor.

Cathode catalyst is another important factor that influences the performance of MFC-based biosensors. In traditional, the cathode in MFC is usually doped with expensive precious metals (e.g., platinum). A study demonstrated that using $\mathrm{FePO}_{4}$ nanoparticles (NPs) as the cathode catalyst instead of $\mathrm{Pt} / \mathrm{C}$ could improve the sensitivity of MFC-based biosensors. Moreover, this assembled sensor device could dramatically facilitate the voltage output from SCMFC, which provides a powerful guarantee for toxicant detection [31].

Anode chamber is widely used as the sensing element in MFC biosensor; however, the output electric signal of the anodic compartment is easily affected by various parameters. The use of biocathode could greatly reduce the false early warning caused by organic matters or toxicity substrates, which has been extensively applied in MFC for remediation, electric power production and quantification of chemical substrate [93,94]. The amelioration of traditional MFC sensor using biocathode as sensing element achieved a very low detection limit and improved sensitivity for toxicity monitoring [77]. Previous studies demonstrated the hydrodynamic shear rate could restrain production of extracellular polymeric substances and biofilm structures [72]. The work investigated by Shen et al. [71] suggested that under low flow rate with intermittent nitrogen surging could enhance the sensitivity of MFCs as toxicity biosensors.

In MFC biosensors, two flow configurations are employed. One is flow-through and the other hand is flow-by mode. The controlled anode potential (CP) mode delivered better sensitivity than 
those operated in the constant external resistance (ER) mode over a broad range of anode potentials from $-0.41 \mathrm{~V}$ to $+0.1 \mathrm{~V}$ [95]. In addition, anode modifications can improve the performance of a VFA biosensor, and among of six different natural or electroplating polymers tested, poly (pyrrole-alkyl ammonium) resulted in a faster start-up of MFC-based biosensor, while providing improved stability, repeatability and recovery of shorter signal response [96].

\subsection{Modification of the MFC-Based Biosensors Model}

To obtain an accurate signal from a MFC-based biosensor, the overpotential in the anodic chamber should be sustained at a stable baseline. However, various overpotentials could affect the sensitivity of a biosensor. Therefore, it is imperative to investigate the overpotential at which the sensor is most sensitive for the detection of toxicants. Taking consideration of type of toxic matter added to anode compartment, the Butler-Volmer-Monod (BVM) model is also useful to evaluate the influence of overpotential in MFCs [28].

Based on parameter values and data obtained from experimental results carried out under non-toxic conditions, four modified models were applied to fit of the experimental results and the predicted overpotential that contributes to the most sensitive sensor. From this study, the authors verified the overpotential at $250 \mathrm{mV}$ mainly influences the substrate affinity constant $(\mathrm{Km})$ and bacterial metabolism. The most sensitive setting for components is at $105 \mathrm{mV}$ overpotential, which affects the ratio of biochemical to electrochemical reaction rate constant (K1). When overpotential ranges between $118 \mathrm{mV}$ and $140 \mathrm{mV}$, the biosensor is sensitive toward toxic component detection and robust against changes in the model parameter $K 2$ under the simulated conditions [97].

Although mathematical models of MFC-based biosensors have been evaluated [28], there is very little quantitative information about their response peaks. The coefficients $\left(R^{2}\right)$ between current (cell potential) and oxygen demand (i.e., COD or BOD) have been widely used to assess the performance of MFC-based biosensors; however, it varies greatly. Because this parameter hardly considers the complex relationships between water quality and MFC output, it may provide misleading information. Therefore, there is an urgent need for better MFC output metrics. Feng et al. [98] carried out integrations using two non-linear programming methods, artificial neural networks (ANN), and time series analysis (TSA), to evaluate the performance of MFC-based biosensor. The MFCs generated well-organized, normally-distributed peaks at $150 \mathrm{mg} \mathrm{L}^{-1} \mathrm{COD}$ or less, while multi-peak signals were obtained at $200 \mathrm{mg} \mathrm{L}^{-1}$ COD. ANN predicted the COD concentration accurately with just one layer of hidden neurons, and the TSA model predicted successfully the temporal trends occurring in properly functioning MFCs and in a device that was gradually failing.

\section{Challenges and Future Prospects}

As mentioned before, MFC-based biosensors provide a potential alternative for monitoring diverse toxins. However, there are some critical challenges that limit their practical application, such as the low selectivity and relatively expensive PEM and cathode catalyst. Besides, anaerobic sludge from diverse areas contains different microbial communities. This variation in EAMs introduces a lack of repeatability and is the main limitation of MFC-based biosensors. How to eliminate the above-mentioned challenges and improve the application ability of MFC-based biosensors needs further study.

To improve the current generation and reduce the response time of MFC-based biosensors, the MFCs design needs to focus on decreasing the internal electrical resistance. Screening new anodophilic microbes, microbes groups or consortia with efficient substrate utilization is also important. Very recently, a study demonstrated that one type of bacterium in the consortium can use the electron mediators that are provided by another type of bacterium to transport electrons more efficiently [83]. In addition, the maximum current output from a single MFC could be limited to meet the practical application. By combining the appropriate number of stacked MFC, in theory, we can obtain any desired current or voltage. 
Genetically engineered microorganisms based on fusing of receptor and/or reporter proteins to an inducible gene promoter have been widely applied to detect specific toxins. Nonetheless, we still lack effective methods to improve the selectivity of MFC-based biosensors. As the electronic transport mechanism of MFCs is gradually elucidated, it is conceivable to construct genetically engineered bacteria with the ability to reflect the concentration of a given substrate into a voltage output in a MFC biosensor. Besides, many factors can affect the electrogenesis capacity of microorganisms. For example, the extracellular electron mediator (EEM) secreted by bacteria can increase the Coulombic yield of MFCs. Combined with specific receptor proteins of toxins and the EEM regulatory system, it may be possible to fabricate a MFC-based biosensor with high selectivity. In addition, the deletion of key functional genes of EAMs can contribute to improving its substrate specificity, which also is one of promising approaches to enhance the selectivity of MFC-based biosensors.

For easy maintenance and fabrication, MFC-based biosensors should be simplified and portable. Employing modular components and miniaturization design could be useful for the convenient use and mobile operations. Di Lorenzo et al. [24] demonstrated 3D printed devices could provide an effective method for the preliminary design of SCMFC biosensors. From the perspective of economics, noble PEM and cathode catalysts should be instead replaced by other more cost-effective materials. Membrane-less designs are also regarded promising method and ones with the desired output power have been proposed [9].

Although many studies have investigated the performance of MFC-based biosensors in actual effluents, it is essential to explore the sensorial behavior in real contexts since the long-term operation could change the parameters of this system. Furthermore, MFC biosensors must be able to recognize toxic substances in mixed environments and provide a stable output signal. For mixed cultures, understanding the composition and dynamic variations of microbial communities under different substrates is significant, which could reduce perceived risk and accelerate the adoption of this technology.

A number of studies have been carried out to improve the performance of MFC-based biosensors; nevertheless, these works are mainly focused on the one part of the reactor. It must be pointed out that MFC functions as a system, so partial performance may not be directly affected by other parts and an overall strategy should be adopted to design a MFC-based biosensor. We believe that with the current advances in microbial biosensors and progress in modern biotechnology, microbial biosensors will have a promising and bright future.

\section{Conclusions}

This review summarizes the role of MFC-based biosensors in toxic compound detection; MFC-based biosensors have become a potential alternative tool for the rapid monitoring of different substrates, including compounds (VFA) and combined pollutants (e.g., BOD and COD). The substrate concentration under certain conditions has an impact on the formation and activity of biofilms, resulting in current densities proportional to the concentration of pollutants. Furthermore, in MFC-based biosensors, single substrate monitoring is superior to combined pollutant detection, showing excellent selectivity and sensitivity. Therefore, the implementation of MFC as specific substrate biosensor presents an obvious advantage and provides a novel aspect of MFC application.

Acknowledgments: The present study was supported by National Natural Science Foundation of China grants 31470224 and 31400430, MOST international cooperation grant 2014DFA91340, and Gansu Provincial International Cooperation grant 1504WKCA089-2.

Author Contributions: T.Z. and H.H. wrote the manuscript. J.X. and F.T. prepared the figures. X.L. and L.P revised the paper.

Conflicts of Interest: The authors declare no conflict of interest. 


\section{References}

1. Awasthi, A.K.; Zeng, X.; Li, J. Environmental pollution of electronic waste recycling in India: A critical review. Environ. Pollut. 2016, 211, 259-270. [CrossRef] [PubMed]

2. Song, Q.; Li, J. Environmental effects of heavy metals derived from the e-waste recycling activities in China: A systematic review. Waste Manag. 2014, 34, 2587-2594. [CrossRef] [PubMed]

3. Fujimori, T.; Takigami, H. Pollution distribution of heavy metals in surface soil at an informal electronic-waste recycling site. Environ. Geochem. Health 2014, 36, 159-168. [CrossRef] [PubMed]

4. Baldé, C. The Global e-Waste Monitor 2014: Quantities, Flows and Resources; United Nations University: Tokyo, Japan, 2015.

5. Riget, F.; Vorkamp, K.; Bossi, R.; Sonne, C.; Letcher, R.J.; Dietz, R. Twenty years of monitoring of persistent organic pollutants in Greenland biota. A review. Environ. Pollut. 2016, 217, 114-123. [CrossRef] [PubMed]

6. Abrevaya, X.C.; Sacco, N.J.; Bonetto, M.C.; Hilding-Ohlsson, A.; Cortón, E. Analytical applications of microbial fuel cells. Part II: Toxicity, microbial activity and quantification, single analyte detection and other uses. Biosens. Bioelectron. 2015, 63, 591-601. [CrossRef] [PubMed]

7. Su, L.; Jia, W.; Hou, C.; Lei, Y. Microbial biosensors: A review. Biosens. Bioelectron. 2011, 26, 1788-1799. [CrossRef] [PubMed]

8. Malhotra, B.D.; Chaubey, A. Biosensors for clinical diagnostics industry. Sens. Actuators B Chem. 2003, 91, 117-127. [CrossRef]

9. Pasternak, G.; Greenman, J.; Ieropoulos, I. Self-powered, autonomous biological oxygen demand biosensor for online water quality monitoring. Sens. Actuators B Chem. 2017, 244, 815-822. [CrossRef] [PubMed]

10. Velasquez-Orta, S.B.; Werner, D.; Varia, J.C.; Mgana, S. Microbial fuel cells for inexpensive continuous in-situ monitoring of groundwater quality. Water Res. 2017, 117, 9-17. [CrossRef] [PubMed]

11. Jouanneau, S.; Recoules, L.; Durand, M.J.; Boukabache, A.; Picot, V.; Primault, Y.; Lakel, A.; Sengelin, M.; Barillon, B.; Thouand, G. Methods for assessing biochemical oxygen demand (BOD): A review. Water Res. 2014, 49, 62-82. [CrossRef] [PubMed]

12. Logan, B.E.; Call, D.; Cheng, S.; Hamelers, H.V.; Sleutels, T.H.; Jeremiasse, A.W.; Rozendal, R.A. Microbial electrolysis cells for high yield hydrogen gas production from organic matter. Environ. Sci. Technol. 2008, 42, 8630-8640. [CrossRef] [PubMed]

13. Nevin, K.P.; Kim, B.C.; Glaven, R.H.; Johnson, J.P.; Woodard, T.L.; Methe, B.A.; Didonato, R.J.; Covalla, S.F.; Franks, A.E.; Liu, A.; et al. Anode biofilm transcriptomics reveals outer surface components essential for high density current production in Geobacter sulfurreducens fuel cells. PLoS ONE 2009, 4, e5628. [CrossRef] [PubMed]

14. Inoue, K.; Qian, X.; Morgado, L.; Kim, B.C.; Mester, T.; Izallalen, M.; Salgueiro, C.A.; Lovley, D.R. Purification and characterization of $\mathrm{OmcZ}$, an outer-surface, octaheme c-type cytochrome essential for optimal current production by Geobacter sulfurreducens. Appl. Environ. Microbiol. 2010, 76, 3999-4007. [CrossRef] [PubMed]

15. Malvankar, N.S.; Lovley, D.R. Microbial nanowires for bioenergy applications. Curr. Opin. Biotechnol. 2014, 27, 88-95. [CrossRef] [PubMed]

16. Reguera, G.; McCarthy, K.D.; Mehta, T.; Nicoll, J.S. Extracellular electron transfer via microbial nanowires. Nature 2005, 435, 1098-1101. [CrossRef] [PubMed]

17. Kotloski, N.J.; Gralnick, J.A. Flavin electron shuttles dominate extracellular electron transfer by Shewanella oneidensis. mBio 2013, 4, e00553-12. [CrossRef] [PubMed]

18. Yong, Y.C.; Cai, Z.; Yu, Y.Y.; Chen, P.; Jiang, R.; Cao, B.; Sun, J.Z.; Wang, J.Y.; Song, H. Increase of riboflavin biosynthesis underlies enhancement of extracellular electron transfer of Shewanella in alkaline microbial fuel cells. Bioresour. Technol. 2013, 130, 763-768. [CrossRef] [PubMed]

19. Rabaey, K.; Rodriguez, J.; Blackall, L.L.; Keller, J.; Gross, P.; Batstone, D.; Verstraete, W.; Nealson, K.H. Microbial ecology meets electrochemistry: Electricity-driven and driving communities. ISME J. 2007, 1, 9-18. [CrossRef] [PubMed]

20. Park, D.; Zeikus, J. Utilization of electrically reduced neutral Red byActinobacillus succinogenes: Physiological function of neutral Red in membrane-driven fumarate reduction and energy conservation. J. Bacteriol. 1999, 181, 2403-2410. [PubMed]

21. Park, D.H.; Zeikus, J.G. Electricity generation in microbial fuel cells using neutral red as an electronophore. Appl. Environ. Microbiol. 2000, 66, 1292-1297. [CrossRef] [PubMed] 
22. Chouler, J.; Di Lorenzo, M. Water quality monitoring in developing countries; can microbial fuel cells be the answer? Biosensors 2015, 5, 450-470. [CrossRef] [PubMed]

23. Abrevaya, X.C.; Sacco, N.J.; Bonetto, M.C.; Hilding-Ohlsson, A.; Cortón, E. Analytical applications of microbial fuel cells. Part I: Biochemical oxygen demand. Biosens. Bioelectron. 2015, 63, 580-590. [CrossRef] [PubMed]

24. Di Lorenzo, M.; Thomson, A.R.; Schneider, K.; Cameron, P.J.; Ieropoulos, I. A small-scale air-cathode microbial fuel cell for on-line monitoring of water quality. Biosens. Bioelectron. 2014, 62, 182-188. [CrossRef] [PubMed]

25. Kim, M.; Sik Hyun, M.; Gadd, G.M.; Joo Kim, H. A novel biomonitoring system using microbial fuel cells. J. Environ. Monit. 2007, 9, 1323-1328. [CrossRef] [PubMed]

26. Logan, B.E.; Hamelers, B.; Rozendal, R.; Schröder, U.; Keller, J.; Freguia, S.; Aelterman, P.; Verstraete, W.; Rabaey, K. Microbial fuel cells: Methodology and technology. Environ. Sci. Technol. 2006, 40, 5181-5192. [CrossRef] [PubMed]

27. Stein, N.E.; Hamelers, H.M.V.; van Straten, G.; Keesman, K.J. On-line detection of toxic components using a microbial fuel cell-based biosensor. J. Process Control 2012, 22, 1755-1761. [CrossRef]

28. Hamelers, H.V.M.; ter Heijne, A.; Stein, N.; Rozendal, R.A.; Buisman, C.J.N. Butler-Volmer-Monod model for describing bio-anode polarization curves. Bioresour. Technol. 2011, 102, 381-387. [CrossRef] [PubMed]

29. Yu, D.; Bai, L.; Zhai, J.; Wang, Y.; Dong, S. Toxicity detection in water containing heavy metal ions with a self-powered microbial fuel cell-based biosensor. Talanta 2017, 168, 210-216. [CrossRef] [PubMed]

30. Deng, H.; Jiang, Y.; Zhou, Y.; Shen, K.; Zhong, W. Using electrical signals of microbial fuel cells to detect copper stress on soil microorganisms. Eur. J. Soil Sci. 2015, 66, 369-377. [CrossRef]

31. Zeng, L.; Li, X.; Shi, Y.; Qi, Y.; Huang, D.; Tadé, M.; Wang, S.; Liu, S. FePO 4 based single chamber air-cathode microbial fuel cell for online monitoring levofloxacin. Biosens. Bioelectron. 2017, 91, 367-373. [CrossRef] [PubMed]

32. Wang, G.H.; Cheng, C.Y.; Liu, M.H.; Chen, T.Y.; Hsieh, M.C.; Chung, Y.C. Utility of Ochrobactrum anthropi YC152 in a Microbial Fuel Cell as an Early Warning Device for Hexavalent Chromium Determination. Sensors 2016, 16, 1272. [CrossRef] [PubMed]

33. Davila, D.; Esquivel, J.; Sabate, N.; Mas, J. Silicon-based microfabricated microbial fuel cell toxicity sensor. Biosens. Bioelectron. 2011, 26, 2426-2430. [CrossRef] [PubMed]

34. Wang, X.; Gao, N.; Zhou, Q. Concentration responses of toxicity sensor with Shewanella oneidensis MR-1 growing in bioelectrochemical systems. Biosens. Bioelectron. 2013, 43, 264-267. [CrossRef] [PubMed]

35. Chen, Z.; Niu, Y.; Zhao, S.; Khan, A.; Ling, Z.; Chen, Y.; Liu, P.; Li, X. A novel biosensor for p-nitrophenol based on an aerobic anode microbial fuel cell. Biosens. Bioelectron. 2016, 85, 860-868. [CrossRef] [PubMed]

36. Chae, K.J.; Choi, M.J.; Lee, J.W.; Kim, K.Y.; Kim, I.S. Effect of different substrates on the performance, bacterial diversity, and bacterial viability in microbial fuel cells. Bioresour. Technol. 2009, 100, 3518-3525. [CrossRef] [PubMed]

37. Lei, Y.; Chen, W.; Mulchandani, A. Microbial biosensors. Anal. Chim. Acta 2006, 568, 200-210. [CrossRef] [PubMed]

38. Yang, H.; Zhou, M.; Liu, M.; Yang, W.; Gu, T. Microbial fuel cells for biosensor applications. Biotechnol. Lett. 2015, 37, 2357-2364. [CrossRef] [PubMed]

39. Falk, H.M.; Reichling, P.; Andersen, C.; Benz, R. Online monitoring of concentration and dynamics of volatile fatty acids in anaerobic digestion processes with mid-infrared spectroscopy. Bioprocess Biosyst. Eng. 2015, 38, 237-249. [CrossRef] [PubMed]

40. Raposo, F.; Borja, R.; Cacho, J.; Mumme, J.; Orupõld, K.; Esteves, S.; Noguerol-Arias, J.; Picard, S.; Nielfa, A.; Scherer, P. First international comparative study of volatile fatty acids in aqueous samples by chromatographic techniques: Evaluating sources of error. TrAC Trends Anal. Chem. 2013, 51, 127-143. [CrossRef]

41. Siedlecka, E.; Kumirska, J.; Ossowski, T.; Glamowski, P.; Gołębiowski, M.; Gajdus, J.; Kaczyński, Z.; Stepnowski, P. Determination of volatile fatty acids in environmental aqueous samples. Pol. J. Environ. Stud. 2008, 17, 351-356.

42. Kaur, A.; Kim, J.R.; Michie, I.; Dinsdale, R.M.; Guwy, A.J.; Premier, G.C. Microbial fuel cell type biosensor for specific volatile fatty acids using acclimated bacterial communities. Biosens. Bioelectron. 2013, 47, 50-55. [CrossRef] [PubMed] 
43. Jin, X.; Angelidaki, I.; Zhang, Y. Microbial electrochemical monitoring of volatile fatty acids during anaerobic digestion. Environ. Sci. Technol. 2016, 50, 4422-4429. [CrossRef] [PubMed]

44. Jin, X.; Li, X.; Zhao, N.; Angelidaki, I.; Zhang, Y. Bio-electrolytic sensor for rapid monitoring of volatile fatty acids in anaerobic digestion process. Water Res. 2017, 111, 74-80. [CrossRef] [PubMed]

45. Shen, Y.J.; Lefebvre, O.; Tan, Z.; Ng, H.Y. Microbial fuel-cell-based toxicity sensor for fast monitoring of acidic toxicity. Water Sci. Technol. 2012, 65, 1223-1228. [CrossRef] [PubMed]

46. Schievano, A.; Colombo, A.; Cossettini, A.; Goglio, A.; D'Ardes, V.; Trasatti, S.; Cristiani, P. Single-chamber microbial fuel cells as on-line shock-sensors for volatile fatty acids in anaerobic digesters. Waste Manag. 2017. [CrossRef] [PubMed]

47. Penn, M.R.; Pauer, J.J.; Mihelcic, J.R. Biochemical oxygen demand. Environ. Ecol. Chem. 2009, 2, $278-297$.

48. Butkus, M.A.; Manous, J.D. Biochemical oxygen demand. In Water Encyclopedia; John Wiley \& Sons, Inc.: Hoboken, NJ, USA, 2005.

49. Karube, I.; Matsunaga, T.; Mitsuda, S.; Suzuki, S. Microbial electrode BOD sensors. Biotechnol. Bioeng. 1977, 19, 1535-1547. [CrossRef] [PubMed]

50. Kim, B.H.; Chang, I.S.; Cheol Gil, G.; Park, H.S.; Kim, H.J. Novel BOD (biological oxygen demand) sensor using mediator-less microbial fuel cell. Biotechnol. Lett. 2003, 25, 541-545. [CrossRef] [PubMed]

51. Kang, K.H.; Jang, J.K.; Pham, T.H.; Moon, H.; Chang, I.S.; Kim, B.H. A microbial fuel cell with improved cathode reaction as a low biochemical oxygen demand sensor. Biotechnol. Lett. 2003, 25, 1357-1361. [CrossRef] [PubMed]

52. Moon, H.; Chang, I.S.; Kang, K.H.; Jang, J.K.; Kim, B.H. Improving the dynamic response of a mediator-less microbial fuel cell as a biochemical oxygen demand (BOD) sensor. Biotechnol. Lett. 2004, 26, 1717-1721. [CrossRef] [PubMed]

53. Chang, I.S.; Jang, J.K.; Gil, G.C.; Kim, M.; Kim, H.J.; Cho, B.W.; Kim, B.H. Continuous determination of biochemical oxygen demand using microbial fuel cell type biosensor. Biosens. Bioelectron. 2004, 19, 607-613. [CrossRef]

54. Moon, H.; Chang, I.S.; Jang, J.K.; Kim, K.S.; Lee, J.; Lovitt, R.W.; Kim, B.H. On-line monitoring of low biochemical oxygen demand through continuous operation of a mediator-less microbial fuel cell. J. Microbiol. Biotechnol. 2005, 15, 192-196.

55. Kumlanghan, A.; Liu, J.; Thavarungkul, P.; Kanatharana, P.; Mattiasson, B. Microbial fuel cell-based biosensor for fast analysis of biodegradable organic matter. Biosens. Bioelectron. 2007, 22, 2939-2944. [CrossRef] [PubMed]

56. Di Lorenzo, M.; Curtis, T.P.; Head, I.M.; Scott, K. A single-chamber microbial fuel cell as a biosensor for wastewaters. Water Res. 2009, 43, 3145-3154. [CrossRef] [PubMed]

57. Peixoto, L.; Min, B.; Martins, G.; Brito, A.G.; Kroff, P.; Parpot, P.; Angelidaki, I.; Nogueira, R. In situ microbial fuel cell-based biosensor for organic carbon. Bioelectrochemistry 2011, 81, 99-103. [CrossRef] [PubMed]

58. Zhang, Y.; Angelidaki, I. Submersible microbial fuel cell sensor for monitoring microbial activity and BOD in groundwater: Focusing on impact of anodic biofilm on sensor applicability. Biotechnol. Bioeng. 2011, 108, 2339-2347. [CrossRef] [PubMed]

59. Ayyaru, S.; Dharmalingam, S. Enhanced response of microbial fuel cell using sulfonated poly ether ether ketone membrane as a biochemical oxygen demand sensor. Anal. Chim. Acta 2014, 818, 15-22. [CrossRef] [PubMed]

60. Chang, I.S.; Moon, H.; Jang, J.K.; Kim, B.H. Improvement of a microbial fuel cell performance as a BOD sensor using respiratory inhibitors. Biosens. Bioelectron. 2005, 20, 1856-1859. [CrossRef] [PubMed]

61. Nguyen, T.T.; Luong, T.T.T.; Tran, P.H.N.; Bui, H.T.V.; Nguyen, H.Q.; Dinh, H.T.; Kim, B.H.; Pham, H.T. A lithotrophic microbial fuel cell operated with pseudomonads-dominated iron-oxidizing bacteria enriched at the anode. Microbial Biotechnol. 2015, 8, 579-589. [CrossRef] [PubMed]

62. Tran, P.H.; Luong, T.T.; Nguyen, T.T.; Nguyen, H.Q.; Duong, H.V.; Kim, B.H.; Pham, H.T. Possibility of using a lithotrophic iron-oxidizing microbial fuel cell as a biosensor for detecting iron and manganese in water samples. Environ. Sci. Process. Impacts 2015, 17, 1806. [CrossRef] [PubMed]

63. Liu, B.; Lei, Y.; Li, B. A batch-mode cube microbial fuel cell based "shock" biosensor for wastewater quality monitoring. Biosens. Bioelectron. 2014, 62, 308-314. [CrossRef] [PubMed] 
64. Yi, Y.; Li, X.; Jiang, X.; Xie, B.; Liu, H.; Liang, D.; Zhu, Y. Assessing the solitary and joint biotoxicities of heavy metals and acephate using microbial fuel cell. In Proceedings of the 2015 International Conference on Advances in Energy, Environment and Chemical Engineering, Changsha, China, 26-27 September 2015.

65. Lee, J.S.; Kim, D.S.; Jeon, H.J.; Park, B.S. Microbial fuel cell as a biosensor to monitor various toxic metal substances in water. In Proceedings of the 9th International Conference on Sensing Technology, Auckland, New Zealand, 8-10 December 2015; pp. 416-419.

66. Li, T.; Wang, X.; Zhou, L.; An, J.; Li, J.; Li, N.; Sun, H.; Zhou, Q. Bioelectrochemical sensor using living biofilm to in situ evaluate flocculant toxicity. ACS Sens. 2016, 1, 1374-1379. [CrossRef]

67. Becaria, A.; Campbell, A.; Bondy, S. Aluminum as a toxicant. Toxicol. Ind. Health 2002, 18, 309-320. [CrossRef] [PubMed]

68. Laureanti, J.A.; Jones, A.K. Photosynthetic Microbial Fuel Cells. In Biophotoelectrochemistry: From Bioelectrochemistry to Biophotovoltaics; Springer International Publishing: Switzerland, 2016; pp. 159-175.

69. Strik, D.P.; Terlouw, H.; Hamelers, H.V.; Buisman, C.J. Renewable sustainable biocatalyzed electricity production in a photosynthetic algal microbial fuel cell (PAMFC). Appl. Microbiol. Biotechnol. 2008, 81, 659-668. [CrossRef] [PubMed]

70. Labro, J.; Craig, T.; Wood, S.A.; Packer, M.A. Demonstration of the use of a photosynthetic microbial fuel cell as an environmental biosensor. Int. J. Nanotechnol. 2017, 14, 213-225. [CrossRef]

71. Shen, Y.; Wang, M.; Chang, I.S.; Ng, H.Y. Effect of shear rate on the response of microbial fuel cell toxicity sensor to $\mathrm{Cu}(\mathrm{II})$. Bioresour. Technol. 2013, 136, 707-710. [CrossRef] [PubMed]

72. Tao, X.; Gao, Y.-M.; Zheng, Q.; Wang, X.-H.; Yuan, L.; Nan, L.; Rui, L. A Double-microbial Fuel Cell Heavy Metals Toxicity Sensor. DEStech Trans. Environ. Energy Earth Sci. 2017. [CrossRef]

73. Kim, H.J.; Park, H.S.; Hyun, M.S.; Chang, I.S.; Kim, M.; Kim, B.H. A mediator-less microbial fuel cell using a metal reducing bacterium, Shewanella putrefaciens. Enzym. Microb. Technol. 2002, 30, 145-152. [CrossRef]

74. Ringeisen, B.R.; Henderson, E.; Wu, P.K.; Pietron, J.; Ray, R.; Little, B.; Biffinger, J.C.; Jones-Meehan, J.M. High power density from a miniature microbial fuel cell using Shewanella oneidensis DSP10. Environ. Sci. Technol. 2006, 40, 2629-2634. [CrossRef] [PubMed]

75. Kitagawa, W.; Kimura, N.; Kamagata, Y. A novel p-nitrophenol degradation gene cluster from a gram-positive bacterium, Rhodococcus opacus SAO101. J. Bacteriol. 2004, 186, 4894-4902. [CrossRef] [PubMed]

76. Lee, H.; Yang, W.; Wei, X.; Fraiwan, A.; Choi, S. A microsized microbial fuel cell based biosensor for fast and sensitive detection of toxic substances in water. In Proceedings of the 2015 28th IEEE International Conference on Micro Electro Mechanical Systems (MEMS), Estoril, Portugal, 18-22 January 2015; IEEE: Piscataway, NJ, USA, 2015; pp. 573-576.

77. Jiang, Y.; Liang, P.; Liu, P.; Wang, D.; Miao, B.; Huang, X. A novel microbial fuel cell sensor with biocathode sensing element. Biosens. Bioelectron. 2017, 94, 344-350. [CrossRef] [PubMed]

78. Chatterjee, S.; Chen, A. Functionalization of carbon buckypaper for the sensitive determination of hydrogen peroxide in human urine. Biosens. Bioelectron. 2012, 35, 302-307. [CrossRef] [PubMed]

79. Schreiter, P.P.Y.; Gillor, O.; Post, A.; Belkin, S.; Schmid, R.D.; Bachmann, T.T. Monitoring of phosphorus bioavailability in water by an immobilized luminescent cyanobacterial reporter strain. Biosens. Bioelectron. 2001, 16, 811-818. [CrossRef]

80. Casavant, N.C.; Thompson, D.; Beattie, G.A.; Phillips, G.J.; Halverson, L.J. Use of a site-specific recombination-based biosensor for detecting bioavailable toluene and related compounds on roots. Environ. Microbiol. 2003, 5, 238-249. [CrossRef] [PubMed]

81. Yang, W.; Wei, X.; Fraiwan, A.; Coogan, C.G.; Lee, H.; Choi, S. Fast and sensitive water quality assessment: A $\mu$ L-scale microbial fuel cell-based biosensor integrated with an air-bubble trap and electrochemical sensing functionality. Sens. Actuators B Chem. 2016, 226, 191-195. [CrossRef]

82. Xu, X.; Ying, Y. Microbial biosensors for environmental monitoring and food analysis. Food Rev. Int. 2011, 27, 300-329. [CrossRef]

83. Liu, Y.; Ding, M.; Ling, W.; Yang, Y.; Zhou, X.; Li, B.-Z.; Chen, T.; Nie, Y.; Wang, M.; Zeng, B.; et al. A three-species microbial consortium for power generation. Energy Environ. Sci. 2017, 10, 1600-1609. [CrossRef]

84. Choudhury, P.; Prasad Uday, U.S.; Bandyopadhyay, T.K.; Ray, R.N.; Bhunia, B. Performance improvement of microbial fuel cell (MFC) using suitable electrode and Bioengineered organisms: A review. Bioengineered 2017, 1-17. [CrossRef] [PubMed] 
85. Kong, X.; Zhou, X.; Tian, Y.; Wu, X.; Zhang, J.; Zuo, W. Niobium doped lanthanum calcium ferrite perovskite as a novel electrode material for symmetrical solid oxide fuel cells. J. Power Sources 2016, 326, 35-42. [CrossRef]

86. Wu, Y.; Zhang, X.; Li, S.; Lv, X.; Cheng, Y.; Wang, X. Microbial biofuel cell operating effectively through carbon nanotube blended with gold-titania nanocomposites modified electrode. Electrochim. Acta 2013, 109, 328-332. [CrossRef]

87. Liang, P.; Wang, H.; Xia, X.; Huang, X.; Mo, Y.; Cao, X.; Fan, M. Carbon nanotube powders as electrode modifier to enhance the activity of anodic biofilm in microbial fuel cells. Biosens. Bioelectron. 2011, 26, 3000-3004. [CrossRef] [PubMed]

88. Hsieh, M.C.; Cheng, C.Y.; Liu, M.H.; Chung, Y.C. Effects of operating parameters on measurements of biochemical oxygen demand using a mediatorless microbial fuel cell biosensor. Sensors 2015, 16, 35. [CrossRef] [PubMed]

89. Jia, H.; Yang, G.; Wang, J.; Ngo, H.H.; Guo, W.; Zhang, H.; Zhang, X. Performance of a microbial fuel cell-based biosensor for online monitoring in an integrated system combining microbial fuel cell and upflow anaerobic sludge bed reactor. Bioresour. Technol. 2016, 218, 286-293. [CrossRef] [PubMed]

90. Stein, N.E.; Hamelers, H.V.M.; Buisman, C.N.J. Influence of membrane type, current and potential on the response to chemical toxicants of a microbial fuel cell based biosensor. Sens. Actuators B Chem. 2012, 163, 1-7. [CrossRef]

91. Stein, N.E.; Hamelers, H.V.; Buisman, C.N. Stabilizing the baseline current of a microbial fuel cell-based biosensor through overpotential control under non-toxic conditions. Bioelectrochemistry 2010, 78, 87-91. [CrossRef] [PubMed]

92. Fraiwan, A.; Sundermier, S.; Han, D.; Steckl, A.; Hassett, D.; Choi, S. Enhanced Performance of Micro-Electro-Mechanical-Systems (MEMS) Microbial Fuel Cells Using Electrospun Microfibrous Anode and Optimizing Operation. Fuel Cells 2013, 13, 336-341. [CrossRef]

93. Bergel, A.; Féron, D.; Mollica, A. Catalysis of oxygen reduction in PEM fuel cell by seawater biofilm. Electrochem. Commun. 2005, 7, 900-904. [CrossRef]

94. Si, R.-W.; Zhai, D.-D.; Liao, Z.-H.; Gao, L.; Yong, Y.-C. A whole-cell electrochemical biosensing system based on bacterial inward electron flow for fumarate quantification. Biosens. Bioelectron. 2015, 68, 34-40. [CrossRef] [PubMed]

95. Jiang, Y.; Liang, P.; Zhang, C.; Bian, Y.; Yang, X.; Huang, X.; Girguis, P.R. Enhancing the response of microbial fuel cell based toxicity sensors to $\mathrm{Cu}(\mathrm{II})$ with the applying of flow-through electrodes and controlled anode potentials. Bioresour. Technol. 2015, 190, 367-372. [CrossRef] [PubMed]

96. Kaur, A.; Ibrahim, S.; Pickett, C.J.; Michie, I.S.; Dinsdale, R.M.; Guwy, A.J.; Premier, G.C. Anode modification to improve the performance of a microbial fuel cell volatile fatty acid biosensor. Sens. Actuators B Chem. 2014, 201, 266-273. [CrossRef]

97. Stein, N.E.; Keesman, K.J.; Hamelers, H.V.M.; van Straten, G. Kinetic models for detection of toxicity in a microbial fuel cell based biosensor. Biosens. Bioelectron. 2011, 26, 3115-3120. [CrossRef] [PubMed]

98. Feng, Y.; Kayode, O.; Harper, W.F., Jr. Using microbial fuel cell output metrics and nonlinear modeling techniques for smart biosensing. Sci. Total Environ. 2013, 449, 223-228. [CrossRef] [PubMed]

(C) 2017 by the authors. Licensee MDPI, Basel, Switzerland. This article is an open access article distributed under the terms and conditions of the Creative Commons Attribution (CC BY) license (http://creativecommons.org/licenses/by/4.0/). 